\title{
LA PRIMERA COLECCIÓN DE VISTAS DE LA MEZQUITA-CATEDRAL DE CÓRDOBA EN EL VOYAGE DE LABORDE (1812)
}

\author{
Antonio GÁmiz Gordo y Antonio Jesús García Ortega \\ Universidad de Sevilla
}

\begin{abstract}
La presente investigación se dedica a la primera colección de vistas de la Mezquita-Catedral de Córdoba, incluidas en la monumental obra de Alexandre de Laborde, Voyage pittoresque et historique de l'Espagne (tomo II, 1812). A pesar de la gran calidad de los grabados y dibujos originales sobre Córdoba, su conjunto no contaba con estudio alguno. Nuestro análisis valora su fiabilidad y su aportación documental al conocimiento del singular edificio cordobés y sus transformaciones arquitectónicas. Tras una aproximación al contexto biográfico e histórico de Laborde y del Voyage, las imágenes se estudian agrupadas según sus puntos de vista: visiones de la ciudad, las primeras vistas conocidas del patio, novedosas vistas interiores, más una breve reseña sobre planos y detalles, en parte copiados de otros anteriores.

Palabras clave: Laborde; Vistas; Dibujos; Grabados; Colección; Voyage; Mezquita; Catedral; Córdoba; Siglo XIX; 1812; Vauzelle; Ligier; MNAC; Patrimonio; Ciudad; Paisaje; Arquitectura.
\end{abstract}

\section{THE FIRST COLLECTION OF VIEWS OF THE MOSQUE-CATHEDRAL OF CORDOBA IN LABORDE'S VOYAGE (1812)}

The present study deals with the first collection of views of the Mosque-Cathedral of Cordoba, included in Alexandre de Laborde's huge work, Voyage pittoresque et historique de l'Espagne (volume II, 1812). Despite the fine quality of these original drawings and engravings of Cordoba, the collection has never been examined. Our analysis evaluates its reliability and its documentary contribution to knowledge of this singular edifice in Cordoba and all its architectural transformations. Following an overview of the biographical and historical context of both Laborde and his Voyage, the images are studied in groups according to their points of view: panoramas of the city, the first-known images of the patio, novel interior views, followed by a brief review of plans and details, in part copied from earlier ones.

Key words: Laborde; Views; Drawings; Engravings; Collection; Voyage; Mosque; Cathedral; Cordoba; $19^{\text {th }}$ century; 1812; Vauzelle; Ligier; MNAC; Heritage; City; Landscape; Architecture. 
El Voyage pittoresque et historique de l'Espagne ${ }^{1}$ (1806-1820) es una monumental obra gráfica que incluye en sus dos tomos (con dos partes cada uno) un total de 272 láminas o graba$\operatorname{dos}^{2}$, con vistas y planos resultantes del trabajo de un equipo de excelentes dibujantes dirigido y costeado por Alexandre de Laborde, también dibujante y redactor del texto. En su recorrido por la España de principios del siglo XIX acometieron un pionero ejercicio de catalogación gráfica del patrimonio paisajístico, arquitectónico y arqueológico de la época.

Esta obra suele enmarcarse en el ámbito de la literatura de viajes, un género característico del siglo XIX, destacando su contribución e influencia en los estereotipos culturales de los viajeros extranjeros que por entonces visitaron España ${ }^{3}$. No obstante, desde un punto de vista arquitectónico y paisajístico, su mayor aportación son, sin duda, sus imágenes, complementadas con textos explicativos. Éstas ofrecen abundantes pormenores sobre muchos lugares hoy transformados y que no contaban con dibujos, o sólo eran esquemáticos o parciales. Por ello tienen gran valor como testimonio visual de una época en la que no existía la fotografía como registro documental. Aunque la Mezquita-Catedral de Córdoba contaba con planos y alguna vista suelta, el Voyage aporta su primera colección de vistas con novedosos encuadres aquí estudiados, además de planos y detalles.

Al tratar de contextualizar las vistas analizadas se ha constatado que no son demasiados los autores que han estudiado con profundidad esta singular obra y sus imágenes, a pesar de su indudable interés. Seguidamente se citan algunos de los trabajos más importantes, omitiendo algunos estudios locales o puramente descriptivos, así como diccionarios biográficos o bibliográficos.

Tras publicaciones de menor entidad a lo largo del XIX, en 1943 Elías Tormo publicó un destacado texto que reivindicaba la figura de Laborde, con motivo del centenario de su fallecimiento, en el Boletín de la Real Academia de la Historia ${ }^{4}$. En 1974-75 aparecieron sendos libros dedicados a Cataluña y Valencia más las Islas Baleares ${ }^{5}$, con mediocres reproducciones, propias de aquellos años, precedidas de estudios críticos. En 1984 María Dolores Cabra publicó un breve artículo que pretendía enmarcar al autor en el contexto de una España prerromántica ${ }^{6}$, e igualmente han aparecido otras muchas obras sobre el romanticismo, viajeros del XIX o publicaciones locales sobre Sevilla, Granada, Toledo... que citan a Laborde o han usado sus vistas como ilustraciones, sin profundizar en su análisis ${ }^{7}$. Entre ellas debe destacarse un libro de 2004 sobre Laborde y Mérida que trasciende lo meramente local ${ }^{8}$. Otro libro de 2006, Viaje por España tras los pasos de Laborde, incluye un cuidadoso prólogo y compagina una selección de grabados con fotos actuales, más un texto periodístico. En 2007 se publicó un artículo de Nuria Llorens ${ }^{10}$ abordando el contexto de los viajes pintorescos de aquel tiempo. Además, en 1960 y 1989 aparecieron en Barcelona catálogos con dibujos preparatorios del Voyage ${ }^{11}$, a los que siguió una exposición en 2006, en el Museu Nacional d'Art de Catalunya, para conmemorar el bicentenario de su edición. En su importante catá-

\footnotetext{
${ }^{1}$ Queremos expresar nuestro agradecimiento a D. Rafael Manzano Martos, maestro y amigo. También a D. Carlos Sánchez y D. Eduardo Páez, que han permitido el acceso a los grabados originales del Voyage de sus colecciones particulares. La traducción al castellano del texto del tomo II (1812) ha sido facilitada por D. Eduardo Páez.

${ }^{2}$ La cifra total de 272 láminas con vistas, cuyo desglose se detalla después, difiere con autores que a veces contabilizan vistas agrupadas en una sola lámina, ascendiendo el número hasta cerca de 350 .

${ }^{3}$ Quilez i CORELla, 2006: 244-248.

4 TORMO, [1943] 1944.

5 LABORDE, [1806] 1974. Laborde, [1811] 1975.

${ }^{6}$ CABRA LOREDO, 1984: 23-32.

7 Sobre Córdoba véase: Nieto Cumplido, LuCa de Tena y Alvear, 1992; Cosano Moyano, 1999.

8 Caballero Rodríguez, 2004.

9 Moret, Mora y Pedraza, 2006.

${ }^{10}$ LLORENS, 2007: 159-176.

11 Laborde [h. 1800-1806], 1960. Laborde [h. 1800-1806], 1989.
} 
logo participaron muchos autores con aportaciones desiguales ${ }^{12}$, incluyéndose un breve estudio sobre Córdoba que trata los textos de Laborde, aunque sólo cita una vista de la ciudad ${ }^{13}$. En la muestra se expusieron 71 dibujos preparatorios del Voyage: 22 de la Bibliothèque de l'Institut National d'Histoire de l'Art de París, algunos de colecciones particulares, y el resto del propio museo, que cuenta en sus fondos con más de 160 originales reseñados en el catálogo.

Al consultar los fondos de la biblioteca parisina citada se ha constatado que allí se conservan (col. Jacques Doucet) un total de 255 dibujos originales preparatorios del Voyage, muchos de los cuales no llegaron a grabarse. Aunque algunos han sido citados ${ }^{14}$ o publicados, debe subrayarse que es poco conocida tan notable cifra de dibujos, hoy digitalizados y a disposición del público interesado. Dicho material abre nuevas expectativas para el estudio de la obra gráfica de Laborde, aún pendiente en muchos lugares de nuestra geografía, y que aquí se acomete por primera vez sobre la Mezquita-Catedral de Córdoba.

\section{Datos biográficos sobre Laborde y su contexto histórico}

Louis Joseph Alexandre de Laborde (fig. A) fue un singular y polifacético personaje que abarcó muy diversos ámbitos del conocimiento humano: fue militar, diplomático, político, economista, pedagogo, arqueólogo, historiador, dibujante... Nació en París el 17 de septiembre de 1773 y murió en dicha ciudad el 20 de octubre de 1842. Pertenecía a la alta burguesía, a una familia dedicada al comercio y las finanzas. Su padre, JeanJoseph de Laborde (1724-1794) nació en Jaca (Huesca) -lo cual justifica el interés de su hijo por asuntos españoles- y reunió una gran fortuna como banquero para Luis XV y Luis XVI, aunque acabó guillotinado en la Revolución Francesa ${ }^{15}$.

En 1788, ante la grave situación de la monarquía en Francia, Alexandre de Laborde vivió un exilio de cerca de 10 años en los que viajó por distintos países de Europa. Uno de esos viajes, en 1796, le llevaría a Monserrat ${ }^{16}$, un lugar por el que sentiría fascinación y al que se dedican bastantes grabados del Voyage. En 1797, instalada la paz, regresó a Francia y supo vincularse a las esferas del poder político, de forma que su actividad como hombre de letras y su interés por las artes estuvo siempre ligada a su importante carrera política.

Por entonces en Europa se vivían convulsos tiempos de transición del antiguo régimen

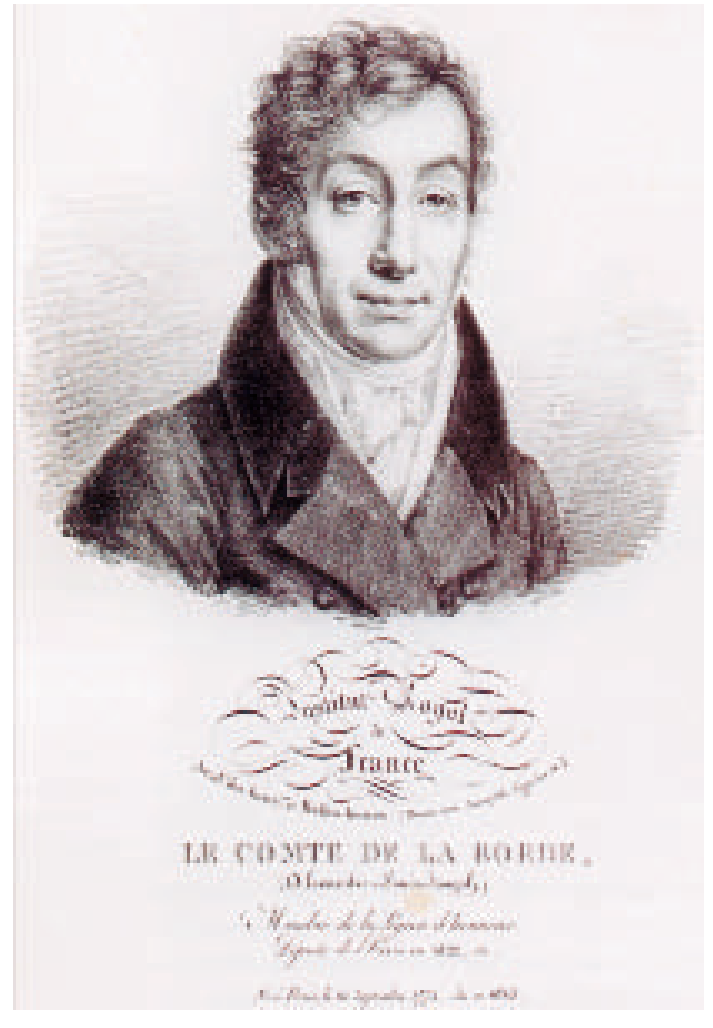

Fig. A. Retrato de Alexandre de Laborde realizado en 1813. Boilly fils (lit.).

12 Casanovas y Quilez, 2006.

13 LÓpez Ontiveros, 2006: 268-269.

14 DAmiron, 1973: 484-486.

15 D'Ormeson y Thomas, 2002.

16 LABORDE, 1806: 17. 
a la modernidad. Godoy había firmado con Francia la paz en 1795, abriendo una época de colaboración entre ambos países, hasta el motín de Aranjuez de 1808. En estos años se sitúa la génesis del Voyage de Laborde, como un asunto de Estado que explica la inclusión en su frontispicio del retrato de Godoy. La corte española afrancesada de Carlos IV impulsó los inicios de este proyecto editorial para dar a conocer las antigüedades de España, imitando a otras naciones que ya tenían su viaje pintoresco, "para eternizar por el dibujo y el grabado lo que la voracidad del tiempo podía llevarse" 17 .

Por entonces se vivían también importantes cambios culturales o de sensibilidad. El mundo empezaba a conocerse mejor gracias a los testimonios literarios y gráficos de los viajeros que lo exploraban, a veces con fines formativos, como ocurría con los Grand Tour desde el siglo XVIII, o a la búsqueda de antigüedades. En este sentido debe advertirse que Laborde no recorrió España como un aventurero o turista romántico, sino buscando información objetiva y actualizada para su posterior publicación. Debe considerarse que el Viage de España de Antonio Ponz ${ }^{18}$ no estaba traducido al francés, y por ello los franceses no contaban con una amplia guía de nuestros territorios.

En el año 1800 Lucien Bonaparte fue nombrado embajador en la Corte de Carlos IV y viajó a Madrid, acompañado de Alexandre de Laborde como agregado cultural. A partir de ese momento éste recorrería España, encabezando un equipo de artistas que reunió abundante material gráfico ${ }^{19}$. Según se indica en el propio texto del Voyage visitó Córdoba en el año 1800. Desde entonces Laborde dedicó gran parte de su esfuerzo y fortuna personal a editar importantes libros, asesorado por destacados personajes, como el escritor François-René de Chateaubriand.

El interés de Laborde por las antigüedades se refleja en su primer libro de tema español, editado en 1802 (con una edición española en 1806) y dedicado al mosaico descubierto en 1799 en las ruinas romanas de Itálica (Sevilla) ${ }^{20}$. Se trata de una lujosa publicación con una tirada de 160 ejemplares, con 104 páginas más 22 láminas grabadas en cobre, realizadas a partir de acuarelas del propio Laborde, también autor de los textos, con la colaboración de eruditos españoles.

En su recorrido por España Laborde recopiló tanta información que decidió publicar otra obra, Itinéraire descriptif de l'Espagne (1808), con cinco volúmenes y un atlas de 29 mapas, que tuvo una segunda edición en 1809, y una tercera y mejor edición hacia 1927-3021. Esta minuciosa guía, que en cierto modo se complementa con el Voyage, reunió copiosos datos sobre distintos lugares de España, incluyendo datos de interés para todo viajero y en especial para los militares franceses que ocuparon nuestros territorios. La principal fuente de los textos de ambas obras sería el citado trabajo de Ponz, y además se usarían textos de Gaspar Melchor de Jovellanos, de Alexander von Humboldt, de la España Sagrada del padre Flórez, etc. También se copiaron planos de diversos autores y láminas publicadas por la Real Academia de San Fernando, según veremos.

El 19 de abril de 1806 la Gaceta de la Corte de España anunciaba el proyecto de un Viaje Pintoresco en España, con 70 cuadernos de seis estampas cada uno, o sea, 420 láminas que debían formar cuatro volúmenes. Los grabados serían obra de los más hábiles artistas de Madrid y de París, y el texto de Alexandre de Laborde ${ }^{22}$. De esta edición española sólo vio la luz la pri-

17 Moret, Mora y Pedraza, 2006: 233.

18 PONZ, 1772-1794.

19 Moret, Mora y Pedraza, 2006: 10-21.

20 LABORDE, 1802. Rueda RoIGÉ, 2004: 7-25.

${ }^{21}$ Hay una versión española publicada en Valencia en 1815 por el padre Villanueva; y dos en 1816 y 1826 del editor Mariano de Cabrerizo y Bascuas, todas con traducción libre.

22 Quilez i Corella, 2006: 250. 
mera parte del primer volumen, en Madrid en 1807 incluyendo el título: Viaje / Pintoresco $e$ histórico / de España, por D. [sic] Alexandro de la [sic] Borde / y una Sociedad de literatos y artistas de Madrid / dedicado / al Serenísimo Señor / Príncipe de la Paz / Generalísimo Almirante de España e Indias. / Dado a luz por D. Antonio Bondeville / Pintor de Cámara [no colaboró en las láminas]. Con privilegio del Rey N. S. En la Imprenta Real / Año M.DCCCVII. El comienzo de la guerra impidió su continuación, pero el trabajo de campo o toma de datos de los siguientes tomos ya se habría realizado, salvo las imágenes de Galicia, Asturias, el Reino de León, el País Vasco y Mallorca, que no llegaron a completarse, aunque en el Itinéraire aparecen textos sobre dichos lugares. Tras la caída de Godoy en 1808, Laborde se llevó las planchas a París y prosiguió allí la publicación, sin la portada de reconocimiento a la monarquía española.

Al finalizar la Guerra de la Independencia, y tras la caída de Napoleón en 1816, el interés por España decaería y el cuarto volumen del Voyage se retrasó hasta 1820. Mientras tanto Laborde acometió publicaciones muy importantes sobre Francia: Description des nouveaux jardins de la France et de ses anciens châteaux, París, 1808-1815; Projets d'embellissement de Paris, 1816; Quarante-huit heures de garde au Château des Tuileries pendant les journées des 19 et 20 mars 1815, París, 1816 (a partir de dibujos del autor); Paris Municipe ou tableaux de l'administration de la ville de Paris, París, 1833; destacando su más conocida obra, Les Monuments de la France classés chronologicament, 1816-1836, con 270 planchas en gran formato de los más emblemáticos monumentos franceses.

Además, hacia 1821-22 publicó en tres lujosos volúmenes su Voyage pittoresque en Autriche, avec un précis historique de la guerre entre la France et l'Autriche en 1809. En 1823 fue autor de Aperçu sur la situation financière de l'Espagne. A partir de 1824 realizó un viaje de cerca de cuatro años por Italia, Grecia, Turquía, Palestina y Egipto en compañía de su hijo, León de Laborde, que dio lugar en 1830 al Voyage en Orient... près de 400 vues et sites historiques de l'Asie Mineur et dela Sirie d'apreès nature, en dos grandes tomos. Entre sus últimas obras destaca un libro ilustrado, Versailles ancien et moderne, 1841.

Laborde publicó durante su vida más de treinta obras sobre viajes, descripciones arqueológicas, textos políticos y económicos, educación, música... Consumió su gran fortuna personal en su pasión por publicar lujosas obras arqueológicas e históricas, ilustradas por artistas de renombre. Sería largo y prolijo completar aquí una reseña con su compleja biografía, que no ha sido objeto de monografía alguna, aunque en la bibliografía citada aparecen bastantes datos sobre su intensa trayectoria hasta su fallecimiento en $1842^{23}$.

\section{Notas sobre el Voyage y sus imágenes}

El Voyage tuvo una doble concepción, gráfica y literaria. Intentaría complacer a sus lectores con un inteligente equilibrio al combinar los placeres de la visión, mediante novedosas ilustraciones de gran calidad, con una miscelánea de textos que aporta datos históricos, arqueológicos, artísticos, científicos, geográficos, etc. Todo ello se aglutinó diluyendo fronteras entre las disciplinas del artista-dibujante, del historiador y del científico.

La obra se organiza en cuatro partes: España romana, árabe, gótica y moderna. El tomo I, sobre la España romana, incluye Cataluña, Valencia y Extremadura. El tomo II en su parte primera, sobre la España árabe, comprende Andalucía. En la segunda parte se considera como España gótica y medieval al País Vasco, Aragón, Asturias y León; y finalmente se aborda la España moderna, en especial Madrid. En cada parte hay una introducción histórica, grabados y textos explicativos.

${ }^{23}$ MeZINSKY, 2006: 235-237. 
De las 70 entregas previstas sólo aparecieron 48. Se publicaron 272 láminas (más un frontispicio y cuatro portadas) en dos tomos de $43 \times 60 \mathrm{~cm}$. La distribución de láminas en la edición francesa es la siguiente:

-t. I, parte primera (1806): 60 láminas ( + frontispicio +2 portadas) de Cataluña

-t. I, parte segunda (1811): 76 láminas (+ portada) de Valencia y Extremadura

-t. II, parte primera (1812): 80 láminas (+ portada) de Andalucía y Gibraltar

-t. II, parte segunda (1820): 57 láminas (+ portada) de Navarra, Aragón y Castilla

El tomo II sobre Andalucía, que aquí nos ocupa (fig. B), contiene 80 láminas, en su mayor parte sobre Córdoba y Granada, más otras sobre Sevilla, Málaga, Cádiz y Gibraltar. De ellas, 17 láminas contienen vistas dobles; debiendo considerarse que otros tomos incluyen vistas dobles, triples y algunas cuádruples.

Esta lujosa publicación vio la luz en la prestigiosa editorial e imprenta de los hermanos Firmin y Pierre Didot, pertenecientes a una saga de impresores franceses que desde el siglo XVIII hicieron de su oficio un arte e industria noble, editando grandes libros de viajes ilustrados con grabados.

Entre los cerca de 20 artistas que colaboraron en el Voyage destacan varios. Jean Lubin Vauzelle (1776-después de 1837), pintor de paisajes y arquitecturas ${ }^{24}$, cuya participación se centró en Andalucía, acometió bellas vistas de la Alhambra y de la Mezquita-Catedral de Córdoba. Sin embargo, fue el arquitecto François Ligier (nacido en 1755, documentado h. 1800-1803) quien firmó un mayor número de láminas, un total de 96, frente a las 31 de Vauzelle; aunque cada uno dedicó ocho láminas a Córdoba. Otros dos importantes autores fueron Jacques Moulinier (1753-1828) con 80 láminas, y Dutailly (documentado h. 1790-1803) con 30 láminas. Hubo colaboradores con menos dibujos: Six con ocho láminas (una de Córdoba), Le Jeune con ocho, Denon con cinco; y Rousseau sólo con dos. Además, el propio Laborde figura como autor de 28 láminas: 12 de Cataluña, nueve de Extremadura y siete de Andalucía; dibujando tanto paisajes (Monserrat) como vistas urbanas (Loja) o restos arqueológicos (Itálica $)^{25}$.

En muchos grabados se omite la firma del dibujante, porque los dibujos serían copias de otros anteriores, como ocurre en los planos de Burgos, Valladolid, Toledo... Otros grabados en los que se indica la autoría también fueron copiados, como los planos de Barcelona, Alicante, Sagunto, Granada... Y muchos planos de la Alhambra y de la Mezquita-Catedral de Cór-

Fig. B. Portada del tomo II del Voyage de Alexandre de Laborde (1812).

\footnotetext{
24 Quesada, 1996: 73.

25 TORMO, [1943: 278] 1944: 20.
} 
doba fueron cuidadosas copias de Las Antigüedades Árabes de España que había publicado la Real Academia de San Fernando (1787 y 1804).

La elección de los lugares que debían dibujarse y de los puntos de vista sería una parte esencial del trabajo acometido. Muchas láminas son el primer testimonio gráfico de la ciudad, paisaje o monumento dibujado. En todo caso los puntos de vista fueron novedosos o aportaron algo respecto a imágenes previas similares, y las distancias o ángulos elegidos para los encuadres suelen ofrecer visiones atractivas y significativas del motivo escogido.

Es importante advertir que el Voyage no incluye vistas fantasiosas o idealizadas ni románticas, porque se usaría cámara oscura para encajar y proporcionar las vistas de forma objetiva, según carta de aquellos años, conservada en el reverso de un dibujo del Monasterio de Montserrat. En dicha carta uno de los hermanos Dumotier, perteneciente a una prestigiosa firma familiar de fabricación de instrumentos ópticos y mecánicos de París, comunica la conclusión de la cámara oscura que se le había encargado ${ }^{26}$.

El uso de este artilugio gráfico, antecedente de la fotografía, podría justificar la inexistencia de firma en la mayoría de los dibujos originales conservados, e incluso hace pensar en la dudosa atribución de algunas autorías. Posiblemente, el propio Laborde o los dibujantes más cualificados elegían puntos de vista y encuadres, mientras sus ayudantes completaban la toma de datos con la cámara oscura. En el caso de Córdoba, los originales conservados y atribuidos a Ligier parecen de idéntica mano que el único original atribuido a Six. Debe advertirse que existen erratas al rotular o transcribir los nombres de los autores en los grabados; e incluso algún grabador figura erróneamente como dibujante ${ }^{27}$. En todo caso, el uso de cámara oscura contribuiría a que la obra mantuviese un estilo gráfico unitario, a pesar del numeroso equipo de artistas y la variedad de temas recogidos. Además, por ello no existen excesivas diferencias de calidad entre las vistas de autores reconocidos, como Vauzelle, y otros menos conocidos, como Ligier o Six. De estos últimos apenas se conocen datos y ni siquiera aparecen en el conocido Benezit, el más completo diccionario de artistas de Francia, seguramente porque no llegaron a participar en importantes exposiciones $^{28}$.

De los dibujos originales conservados se deduce que, en primer lugar, se acometía el encaje a lápiz in situ, captando las proporciones, detalles básicos y principales motivos con cámara oscura, conociéndose una segunda versión de muchos dibujos, con acuarela o aguada, que daría paso a los grabados definitivos, normalmente con pocos cambios. En todo caso se constata el uso de un amplio repertorio de recursos gráficos para componer paisajes, topografías, vegetación o personajes, que recuerda los meticulosos métodos de la pintura paisajística holandesa, italiana o francesa en el XVII y XVIII. También debe destacarse el rigor con el que se acometieron los mapas y planos de arquitectura o restos arqueológicos. Por entonces arte y ciencia compartían objetivos o aspiraciones ${ }^{29}$, y las minuciosas prácticas de observación de los pintores de paisaje eran cercanas a las de los dibujantes científicos. Así, en el Voyage se produjo una singular reunión de imágenes fieles a la realidad, que aportan información objetiva y útil desde un punto de vista histórico, paisajístico, arquitectónico...; pero además casi todas las imágenes son atractivas y, aún sin llegar a ser obras maestras, están realizadas con cierta sensibilidad, e invitan a su contemplación y disfrute.

\footnotetext{
${ }^{26}$ Casanovas y Quilez, 2006: 96.

27 Quilez i Corella, 2006: 251.

${ }^{28}$ Se ha consultado la edición inglesa publicada en 14 vols. (2006).

29 LLORENS, 2007: 164.
} 


\section{La primera colección de vistas de la Mezquita-Catedral}

No se conserva ninguno de los planos y trazas que debieron usarse para erigir tanto la Mezquita, como la posterior Catedral de Córdoba, aunque sí se conocen bastantes vistas y dibujos posteriores. La propia ciudad cuenta con un importante legado de imágenes tomadas casi siempre desde el otro lado del Guadalquivir, encuadrando el puente romano con la ciudad y la MezquitaCatedral detrás, y Sierra Morena al fondo. En 1567 Anton van den Wyngaerde tomó una vista de gran interés, conservada en el Victoria Albert Museum de Londres, en la que las obras de la Catedral cristiana emergen entre las naves de la Mezquita; con gran parecido a otra vista, menos detallada, publicada en el Civitatis Orbis Terrarum en 1617. Durante los siglos XVII y XVIII hubo escasas novedades gráficas, pudiendo destacarse la primera perspectiva interior publicada por Henry Swinburne en Travels through Spain in the years 1775 and 1776 (1779). Por entonces la Real Academia de San Fernando de Madrid editó una obra ya citada, con planos de la Alhambra y la Mezquita-Catedral -copiados por Laborde-, con dos vistas cordobesas de menor interés ${ }^{30}$. En 1813 se publicó la obra del arquitecto James C. Murphy, The Arabian Antiquities of Spain, con cuatro vistas de Córdoba no muy distintas a las de Laborde, aunque su calidad es inferior. Además, otros muchos personajes, largos de enumerar, realizaron vistas de la Mezquita a lo largo del siglo XIX (Taylor, Ford, Lewis, Roberts...) ${ }^{31}$.

Respecto al tomo del Voyage con las vistas cordobesas, como era habitual en los viajes pintorescos por entonces editados, no podía faltar información sobre el estado de los caminos o vías de comunicación. Por ello, las primeras vistas se dedican a Espiel y Bélmez en Sierra Morena, a un valle de dicho lugar y al Puerto de Despeñaperros, importante acceso a Andalucía. Seguidamente aparecen dos vistas de Córdoba, una general y otra exterior de la Mezquita-Catedral, dedicándose las demás láminas cordobesas a dicho edificio, patio e interiores, planos y detalles.

En el Museu Nacional d'Art de Catalunya se conservan, además del original de dicha vista de Bélmez y una portada palaciega que no llegó a grabarse, seis originales a lápiz sobre la Mezquita-Catedral. Aunque no llevan firma, todos se han atribuido a Ligier porque su nombre figura en el correspondiente grabado, menos uno que parece de similar mano, dudosamente atribuido a Six. Hay dos vistas del patio, una (fig. 4a) similar al posterior grabado (fig. 4b) y otra distinta que no se grabó (fig. 5). También hay un original del interior islámico atribuido a Six (fig. 6a), similar al posterior grabado (fig. 6b), y dos interesantes vistas del interior cristiano que no llegaron a grabarse (figs. 11 y 12); más un detalle suelto de un capitel.

$\mathrm{Y}$ en la Bibliothèque de l'Institut National d'Histoire de l'Art de París se conservan dos aguadas originales: una vista de una puerta lateral de la Mezquita (fig. 3a) similar al grabado publicado (fig. 3b) y otra vista interior (fig. 6b) similar al grabado (fig. 6c) y al dibujo a lápiz atribuido a Six (fig. 6a).

Además, aquí se aporta una vista original del interior firmada por Vauzelle, que no llegó a grabarse, hoy en paradero desconocido (fig. 9), según veremos.

A continuación se repasan las citadas imágenes agrupadas según sus puntos de vista. Se comienza por las visiones de la ciudad; después, las primeras vistas conocidas del patio; más las novedosas vistas interiores; finalizando con planos y detalles, que en parte fueron copias.

\footnotetext{
30 RODRÍGUEZ RuIZ, 1992.

31 Nieto Cumplido y Luca de Tena y Alvear, 1992. Cosano Moyano, 1999.
} 


\section{Vistas urbanas}

Figura 1. Plancha V. Vista general de Córdoba, Ligier (dib.), Devilliers (grab.). Esta vista encuadra la Mezquita-Catedral en la ciudad y su territorio, entre el Guadalquivir y las primeras estribaciones de Sierra Morena, según describe el texto que acompaña a la plancha. Está realizada desde la orilla sur del río, el mejor lugar para contemplar su perfil urbano y su conjunto monumental: la Mezquita-Catedral, el palacio Episcopal, el llamado Triunfo de San Rafael, y el antiguo Puente con su puerta renacentista en un extremo y la fortaleza de la Calahorra en el otro. El paisaje se completa en primer plano con los molinos del río y sus azudas, y con algunos hitos urbanos como la cúpula del colegio de Santa Victoria o el gran volumen del templo conventual de San Francisco, recogido con gran precisión. El afán de fidelidad resulta evidente y destaca la ausencia de elementos idealizados o manipulados con fines estéticos. Tan sólo se detectan pequeñas imprecisiones en la torre de la Catedral, que pierde cierta esbeltez, y en la esquemática representación del modesto caserío cordobés.

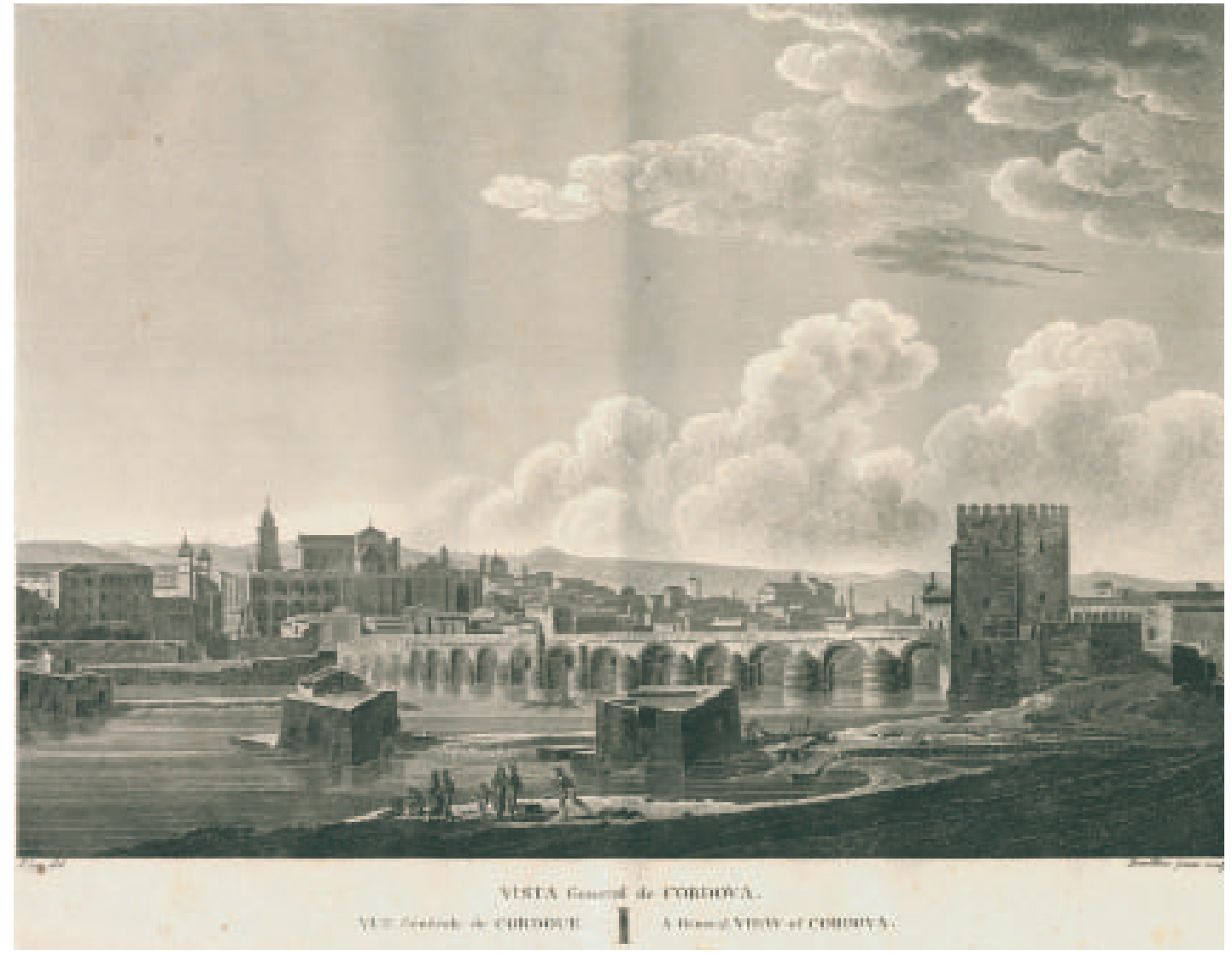

Fig. 1. Plancha V. Vista general de Córdoba. Ligier (dib.), Devilliers (grab.).

Figura 2. Plancha VI. Vista exterior de la Mezquita de Córdoba, Vauzelle (dib.), Schwartz (grab.). La imagen explica cómo se constituye el perímetro del edificio, con un potente muro liso, almenado y con contrafuertes, en el que se insertan las portadas islámicas que marcaban los ac- 


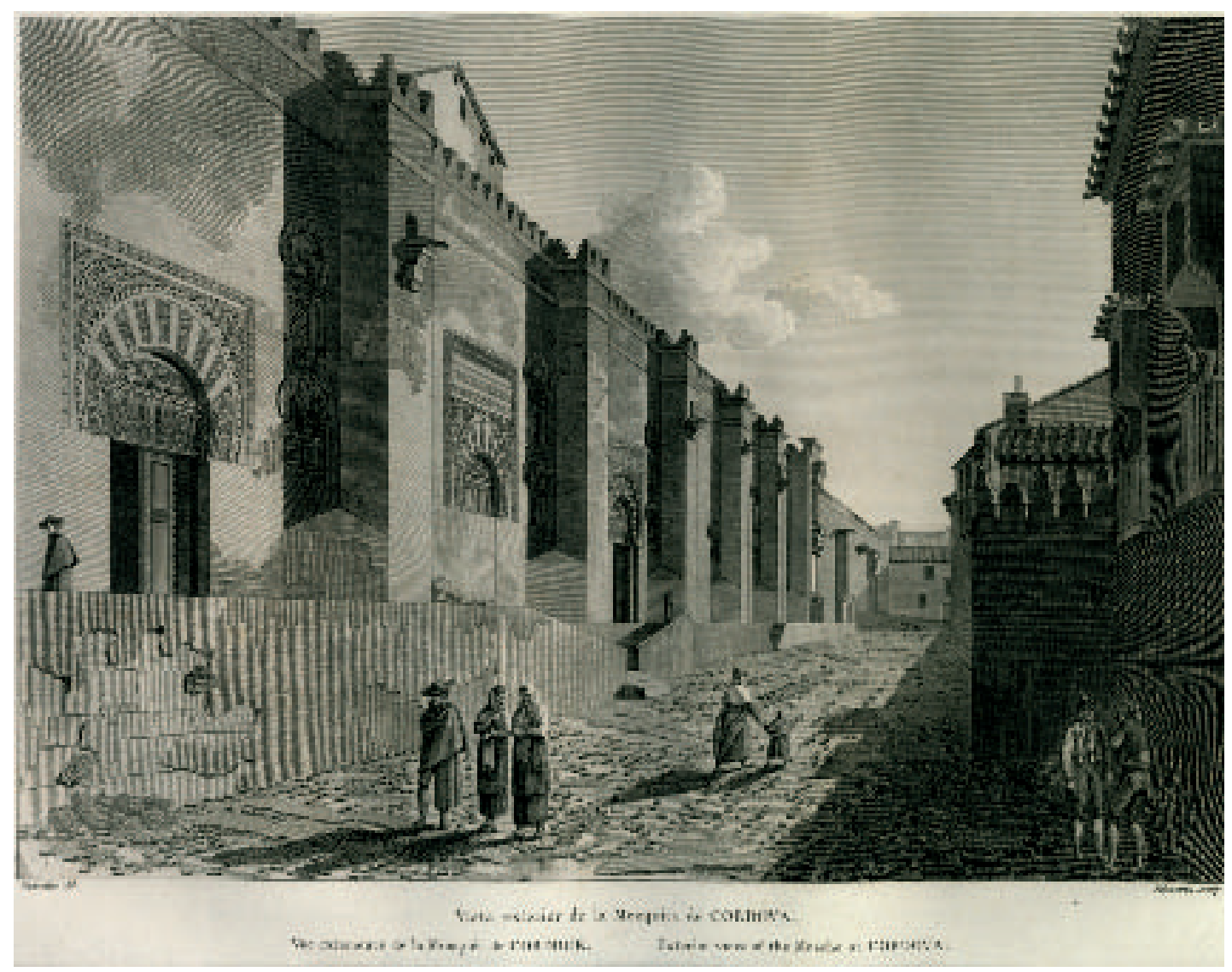

Fig. 2. Plancha VI. Vista exterior de la Mezquita de Córdoba. Vauzelle (dib.), Schwartz (grab.).

cesos al interior. El edificio tuvo que resolver la pendiente decreciente hacia el río con un podium de altura variable, tal y como se precisa en el grabado y en su texto adjunto. Concretamente esta vista recoge la fachada oriental del edificio, debida a la ampliación de Almanzor (h. 987-990), que estaba enlucida en su mayor parte. El documento constituye un preciado testimonio de su estado antes de las intervenciones de Velázquez Bosco que, eliminando enlucidos, restauró y completó sus deterioradas portadas ${ }^{32}$.

\section{Vistas del patio}

Figuras 3a y 3b. Plancha XXI. Puerta lateral de la Mezquita de Córdoba, Ligier (dib.), Schwartz (grab.). Es prácticamente igual al original conservado en la Bibliothèque de l'Institut National d'Histoire de l'Art de París. Estas vistas muestran el patio desde el acceso norte a la Catedral, la "Puerta de las Palmas", formalizada con dos grandes arcos de herradura islámicos.

32 Su proyecto de 1908 se basaba en los restos aparecidos bajo los enlucidos, proponiendo un alzado con idéntica composición para todas las portadas, sólo diferenciadas por sus detalles decorativos. SAN ANTONIO GómEZ, 2008: 180189. Ruiz CABRERO, 1985: 47-56. 


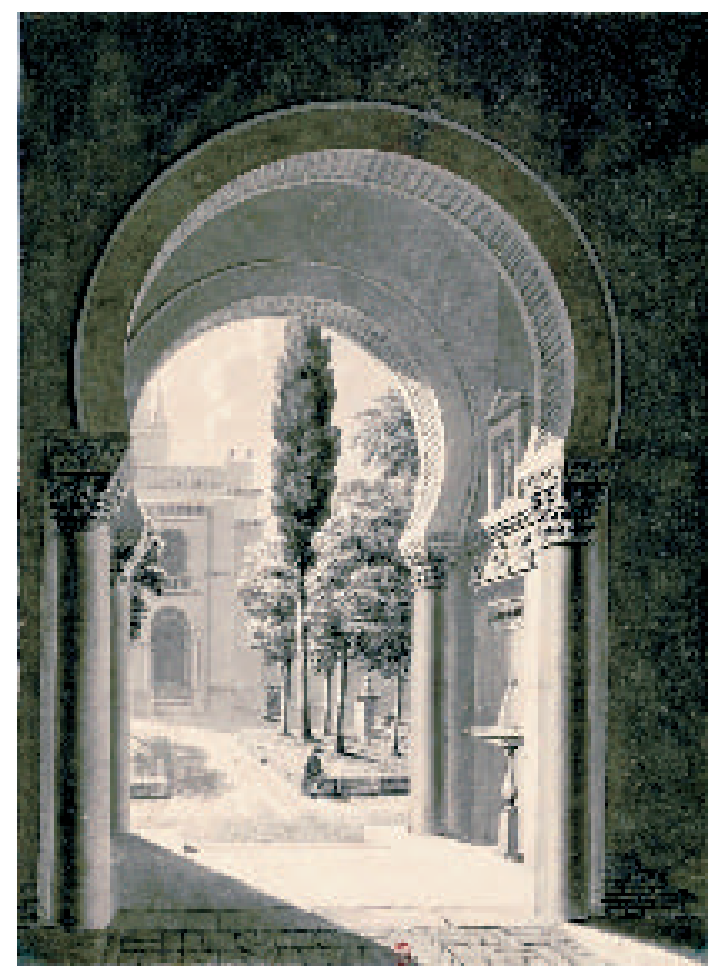

Fig. 3a. Puerta lateral de la Mezquita de Córdoba. [Ligier (dib.)]. Bibliothèque de l'Institut National d'Histoire de l'Art de París (col. Jacques Doucet).

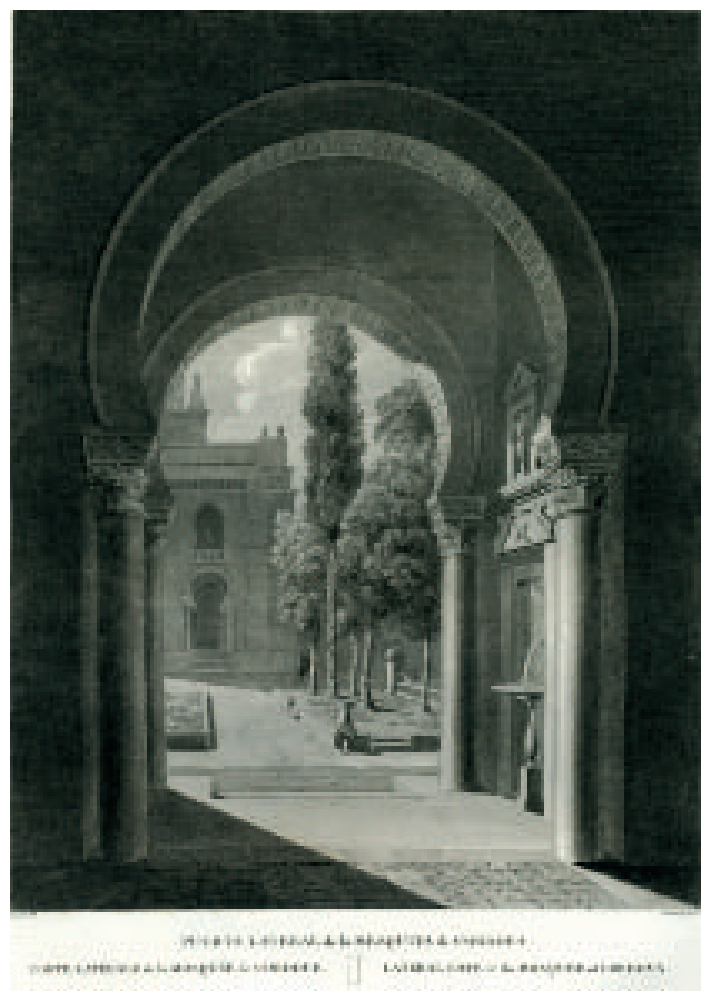

Fig. 3b. Plancha XXI. Puerta lateral de la Mezquita de Córdoba. Ligier (dib.), Schwartz (grab.).

Junto con la puerta contigua al gran alminar conformaba el eje principal del patio, prolongado en el interior del edificio, algo que acertadamente supo recoger la vista. Esto contrasta con la denominación como "Puerta lateral" que figura en el título, denotando un entendimiento del edificio propiciado por la nueva direccionalidad este-oeste impuesta por las intervenciones cristianas. La fuente dibujada en el portal de acceso, también aludida en la descripción escrita, es realmente una pequeña pila de agua bendita que aún hoy existe ${ }^{33}$.

Figuras 4a y 4b. Plancha IX. Vista del jardín de la Mezquita de Córdoba, Ligier (dib.), Baltard (grab.). En el Museu Nacional d'Art de Catalunya se conserva el original a lápiz base de este grabado, con el que guarda total coincidencia. La vista, tomada desde el acceso oriental del patio, encuadra un sencillo jardín, con varios cipreses y una palmera. Constituye un valioso testimonio de la conformación del patio a principios del XIX, con árboles en grandes parterres, que secundaban el suave descenso del terreno, de norte a $\operatorname{sur}^{34}$. La continuidad del pavimento permitía entender unitariamente todo el espacio, hoy algo distorsionado al sobreelevarse y empedrarse el ámbito ajardinado, dejando el arranque de los árboles hundido, y resolviendo el desnivel junto al templo mediante gradas. En la imagen se constata todo lo que ha sobrevivido al paso de dos siglos: en primer plano la fuente del Cinamomo, y a lo lejos, entre el arbolado, la fuente de San-

33 Realizada por Juan Sequero de la Mantilla entre 1617-18. Nieto Cumplido, 1998: 179.

34 Así aparece en el primer plano del edificio, un óleo de 1741 del propio Archivo de la Catedral de Córdoba. Nieto Cumplido y LucA DE Tena y Alvear, 1992: 12. 


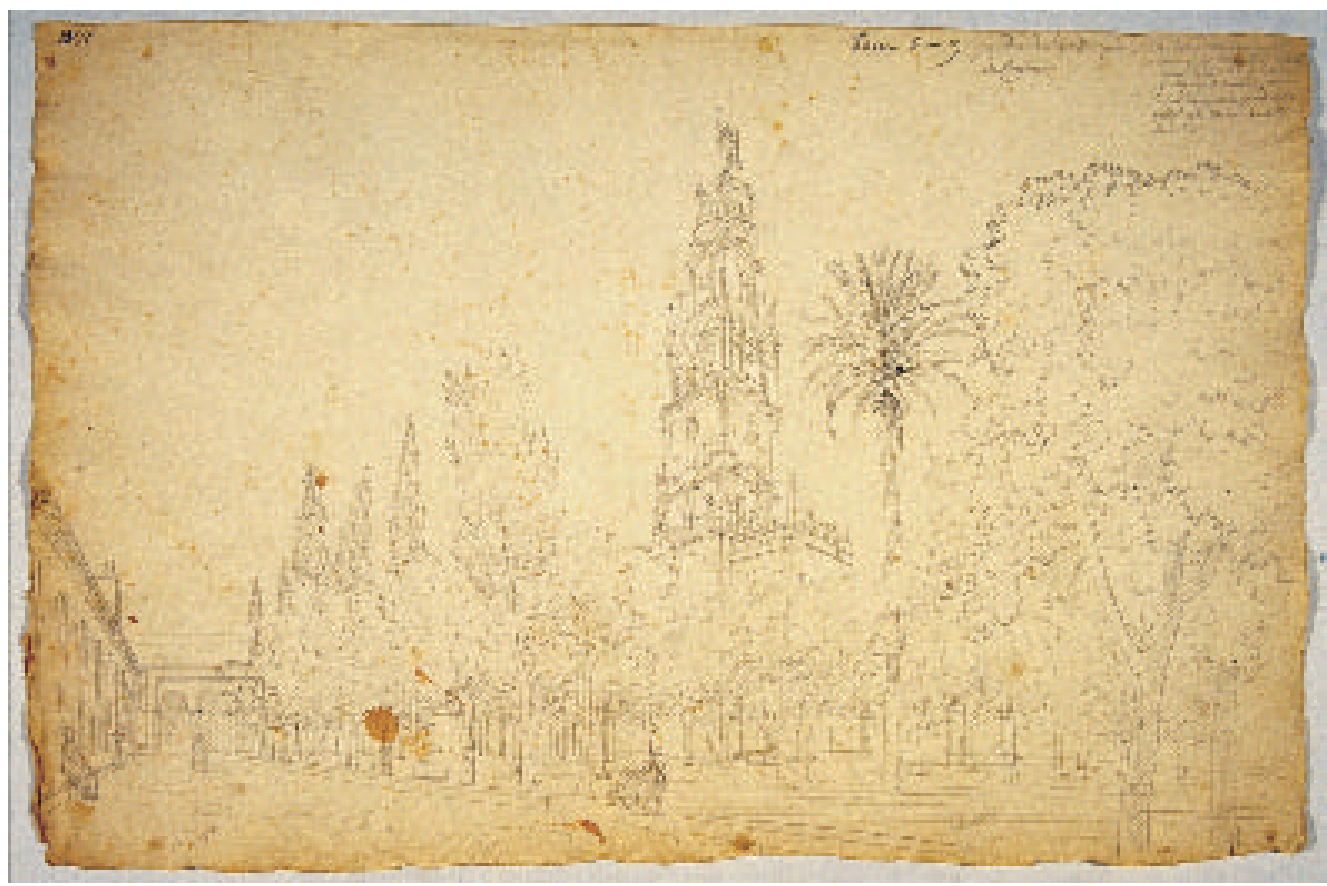

Fig. 4a. Vista del jardín de la Mezquita de Córdoba. [Ligier (dib.)].

(C) MNAC - Museu Nacional d'Art de Catalunya. Barcelona. Fotógrafos: Calveras/Mérida/Sagristà.

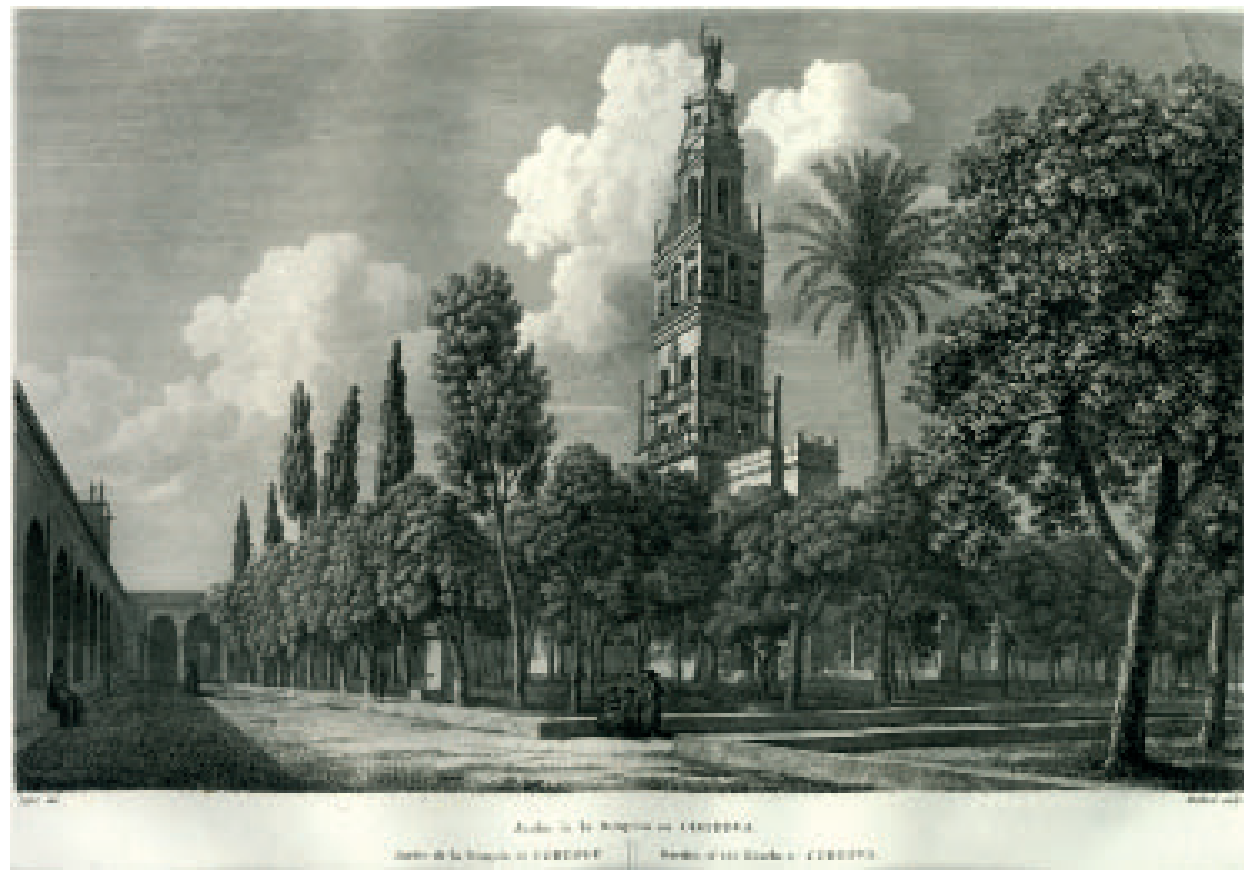

Fig. 4b. Plancha IX. Vista del jardín de la Mezquita de Córdoba. Ligier (dib.), Baltard (grab.).

Arch. esp. arte, LXXXv, 338, ABRIL-JUNIO 2012, 105-124, ISSN: 0004-0428 
ta María, un gran pilón rectangular con cuatro caños en sus esquinas ${ }^{35}$. La torre campanario, plasmada con fidelidad, preside la composición. El afán descriptivo de Laborde le llevó a precisar en su texto elementos tan sólo insinuados en su vista, como el pórtico perimetral, o la cisterna oculta en el subsuelo de la zona dibujada en primer plano.

Figura 5. Jardín y claustro de la Mezquita de Córdoba, dibujo a lápiz atribuido a Ligier (Museu Nacional d'Art de Catalunya). Este dibujo, que no llegó a grabarse, está tomado desde el ángulo noreste del patio, desde la galería perimetral levantada hacia 1510-16 en sustitución de la original islámica. Un arco en primer plano enmarca la composición, con los pórticos norte y oeste, parte del jardín, y la torre campanario según quedó conformada hacia los años $1656-60^{36}$. Todo ello se ajusta con rigor y naturalidad al estado del edificio que hoy puede contemplarse.

\section{Vistas interiores}

Figuras 6a, 6b y 6c. Plancha XII. Entrada principal de la Mezquita de Córdoba, Six [¿o Ligier?] (dib.), Smith (grab.). Se conservan dos dibujos originales preparatorios que parecen de la misma mano que los otros originales de Ligier sobre Córdoba. Uno a lápiz, dudosamente

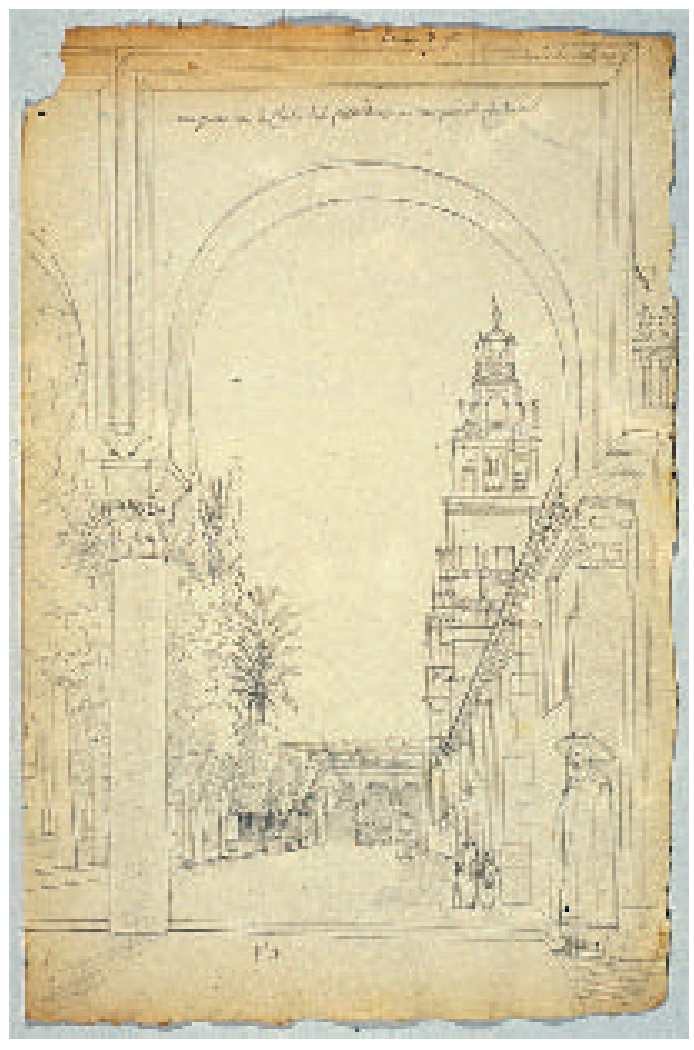

Fig. 5. Jardín y claustro de la Mezquita de Córdoba. [Ligier (dib.)].

(C) MNAC - Museu Nacional d'Art de Catalunya. Barcelona. Fotógrafos: Calveras/Mérida/Sagristà. atribuido a Six, en el Museu Nacional d'Art de Catalunya, y una aguada en la Bibliothèque de l'Institut National d'Histoire de l'Art de París. La vista está tomada otra vez desde la Puerta de las Palmas, pero ahora mirando hacia el interior de la sala de oración islámica. El grabado sigue con fidelidad los dibujos preparatorios, aunque éstos expresaban algo mejor el "bosque de columnas" interior de la Mezquita y sus múltiples lecturas direccionales. El grabado enfatiza algo más la nave central y principal de la primitiva Mezquita de Abderramán I, que se representa con bóvedas y arcos encalados, unas transformaciones cristianas que afortunadamente no supusieron una alteración irreversible de las arcadas ${ }^{37}$. Destaca el esmero con el que se reproducen los variados capiteles reutilizados, así como un singular detalle, las columnas arrancan del suelo sin basas, que estaban enterradas bajo el pavimento a distintas cotas, según constató Félix Hernández (1932-36). Originalmente esta nave unía la entrada principal con el Mihrab, aunque dicho enlace

\footnotetext{
35 Ambas fuentes son obra de Tomás Jerónimo de Pedrajas, de 1726 y 1741. Nieto Cumplido, 1998: 581-84.

36 Según diseño de Hernán Ruiz III, entre 1593 y 1617 se edificó un cuerpo de campanas sobre el antiguo alminar de Abderramán III. Tras amenazar ruina desde 1636, se reforzó revistiendo el fuste islámico entre 1656-60. NIETO Cumplido, 1998: 590-603.

${ }^{37}$ Estas obras las dirigió Juan del Río, maestro mayor h. 1720. Nieto Cumplido, 1998: 113 y 307.
} 


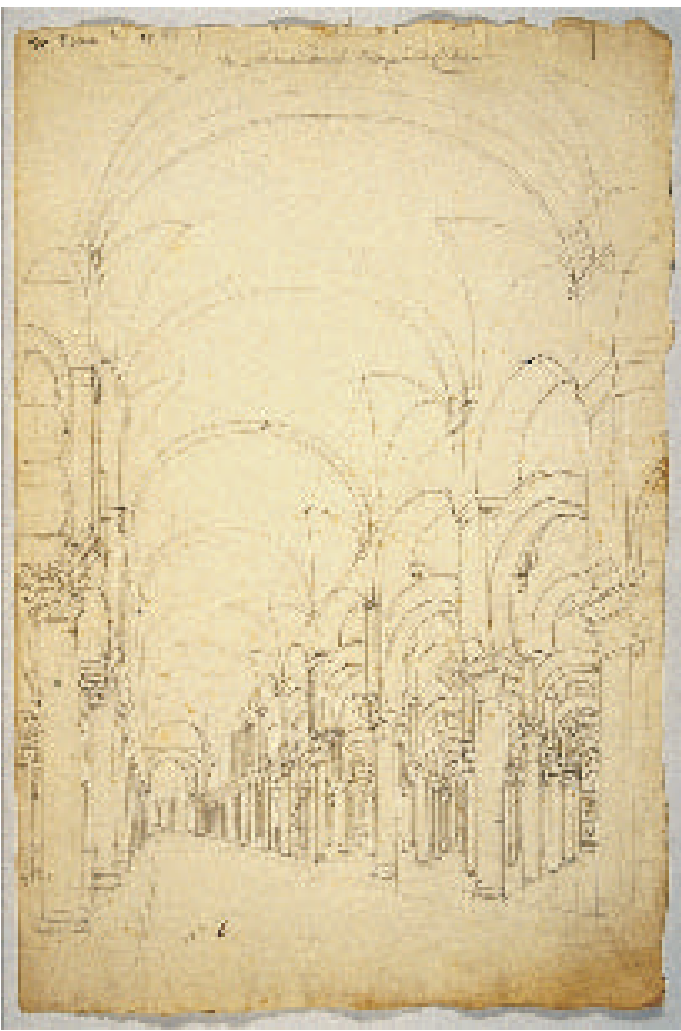

Fig. 6a. Entrada principal de la Mezquita de Córdoba. [¿Six o Ligier? (dib.)].

(C) MNAC - Museu Nacional d'Art de Catalunya.

Barcelona. Fotógrafos: Calveras/Mérida/Sagristà.

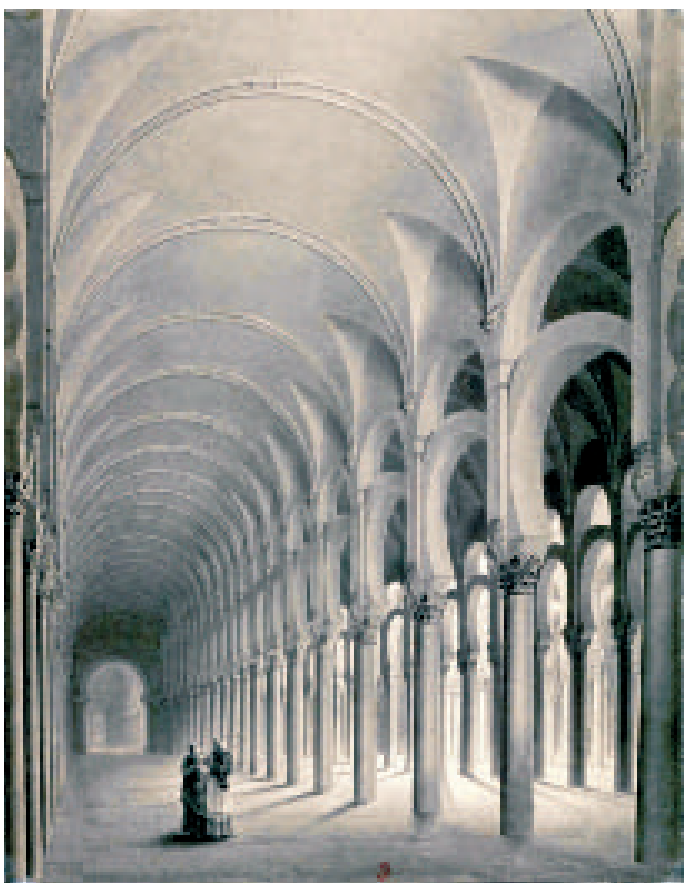

Fig. 6b. Entrada principal de la Mezquita de Córdoba. [¿Six o Ligier? (dib.)].

Bibliothèque de l'Institut National d'Histoire de l'Art de París (col. Jacques Doucet).

se distorsionó con las obras de la nueva catedral emprendidas en el siglo XVI y con las transformaciones del lucernario de al-Hakam $\mathrm{II}^{38}$. El dibujante fue capaz de transmitir la infinitud del lugar y el carácter inconmensurable de este espacio islámico ${ }^{39}$, con una sugerente luz procedente de lucernarios cristianos que apenas alteran la penumbra interior del templo.

Figura 7. Plancha XI. Vista general del interior de la Mezquita de Córdoba, Vauzelle (dib.), Benoist (grab.). En ella puede contemplarse el mágico espacio interior, un "bosque de columnas" infinito que conservaba su carácter islámico, pese a las transformaciones cristianas: bóvedas encamonadas, arcos encalados, lucernarios, distintos altares, la nave gótica construida en 1489 o el tabicado de un sector de la macsura para la capilla funeraria de San Felipe y Santiago, hoy desaparecida. A lo lejos se dibujan los arcos entrelazados que precedían al Mihrab, que para

38 A principios del siglo XIX este espacio era la Capilla de Villaviciosa. Ésta se reconoce nítidamente en el óleo de 1741 ya citado, y figura por última vez en un plano de Velázquez Bosco, fechado en 1891. NieTo Cumplido y LuCA DE Tena y Alvear, 1992: 12, 16, 21, 26. Sobre su conformación original islámica véase MarfiL RuIZ, 1998.

39 El texto que acompaña a esta plancha XII manifiesta tal intencionalidad: “...parece como si nos encontrásemos en medio de un bosque de columnas, que se extendiera a lo lejos del campo, y del que fuese imposible calcular su dimensión". Véase TORRES BALBÁs, 1952; MONEO, 1985: 27-36. 
Laborde es la "sala donde se guardaba el Corán”, y se entrevé la Capilla Real, a la que se dedica la plancha XXV.

Figura 8. Plancha XIII. Vista interior de la Iglesia Mayor de Córdoba, Vauzelle (dib.), Texier (grab.). La imagen reproduce la nave principal del sector añadido hacia el sur por al-Hakam II (961-976), mostrando la complejidad y riqueza decorativa de las arquerías entrecruzadas que delimitaban el espacio de la macsura. Sus ventanas altas la inundaban de luz, alcanzando la penumbra de la sala, que contaba con lucernarios, como el que se intuye arriba en primer plano, hoy desaparecido. Tras la primera y esquemática vista de Swinburne (1779) sobre este lugar, Laborde aporta un valioso testimonio gráfico del Mihrab y de la iluminación cenital que recogen otras imágenes del XIX, como las vistas de David Roberts hacia $1833^{40}$.

Figura 9. Plancha XXV. Vista de la Tribuna Árabe en la Mezquita de Córdoba, Vauzelle (dib.), Hule (grab.). El grabado muestra un controvertido espacio, cuya génesis ha sido objeto de distintas hipótesis, pero que debe lo sustancial de su conformación a las obras acabadas en 1371 para adaptarlo a Capilla Real ${ }^{41}$. La imagen describe el doble nivel de esta

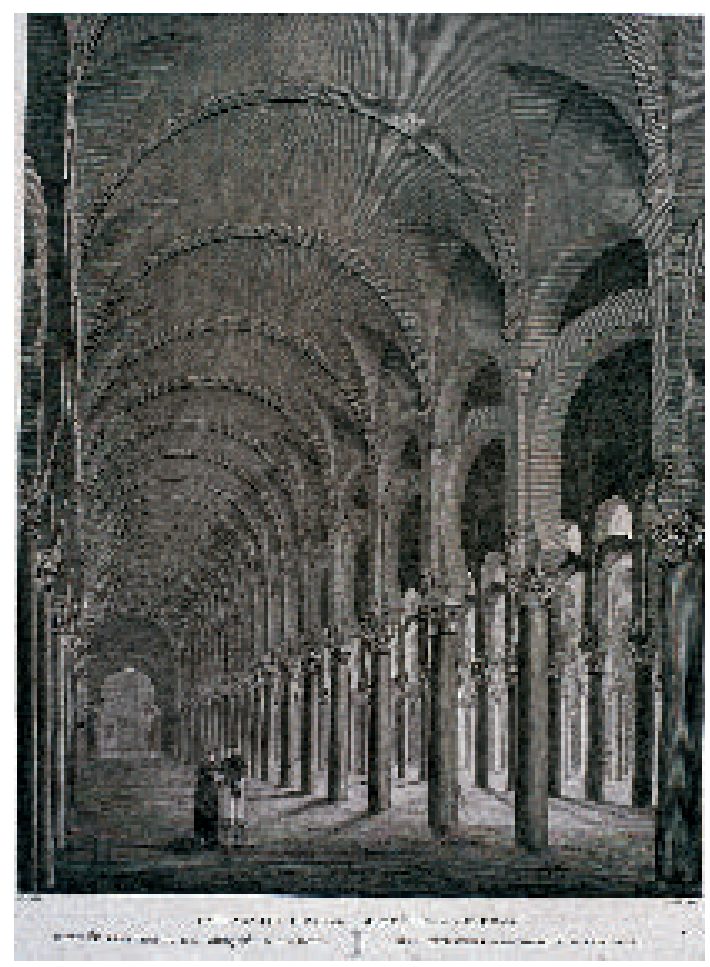

Fig. 6c. Plancha XII. Entrada principal de la Mezquita de Córdoba. Six [¿Ligier?] (dib.), Smith (grab.). construcción, uno a cota inferior del propio pavimento de la Mezquita, la capilla de los Santos Juanes, con entrada por los tres arcos de herradura apuntada; y otro sobreelevado, la Capilla Real, a la que se accedía desde el primitivo presbiterio catedralicio, antes lucernario de alHakam II. Este espacio superior se abre en sus costados norte y sur con dos grandes arcos lobulados, a través de los cuales se percibe la riqueza decorativa de los paramentos interiores.

Figura 10. Vista interior de la Mezquita, Vauzelle (dib.) (original en paradero desconocido) ${ }^{42}$. La reproducción disponible de esta vista, que no llegó a grabarse, incluye la firma de Vauzelle, pero por desgracia la fecha está parcialmente cortada, aunque se aprecia que la última cifra no es un cero. Esto demuestra que la vista no se tomó cuando Laborde visitó el monumento en el año 1800 , sino en años posteriores (1801-1803?) y confirma que hubo una posterior visita a Córdoba con su equipo de dibujantes. Además, esta acuarela a color es distinta a las citadas aguadas originales de la Bibliothèque de l'Institut National d'Histoire de l'Art, todas con un solo tono. Parece peor proporcionada y más esquemática, dando mayor protagonismo a los personajes. Muestra la nave contigua a poniente a la principal del Mihrab, que desembocaba a la puerta de

40 GÁmiz Gordo, 2010: 54-65. Marfil RuIz, 2004: 91-107, ha estudiado arqueológicamente las transformaciones de las tres cúpulas previas al Mihrab, descubriendo su diseño original.

${ }^{41}$ Ésta se conformaría como hoy la conocemos tras las obras promovidas y culminadas en 1371 por Enrique II, según una inscripción en el zócalo. ECKER, 2003: 113-141.

${ }^{42}$ La imagen se reproduce, sin indicar procedencia, en QUESADA, 1996: 73. 


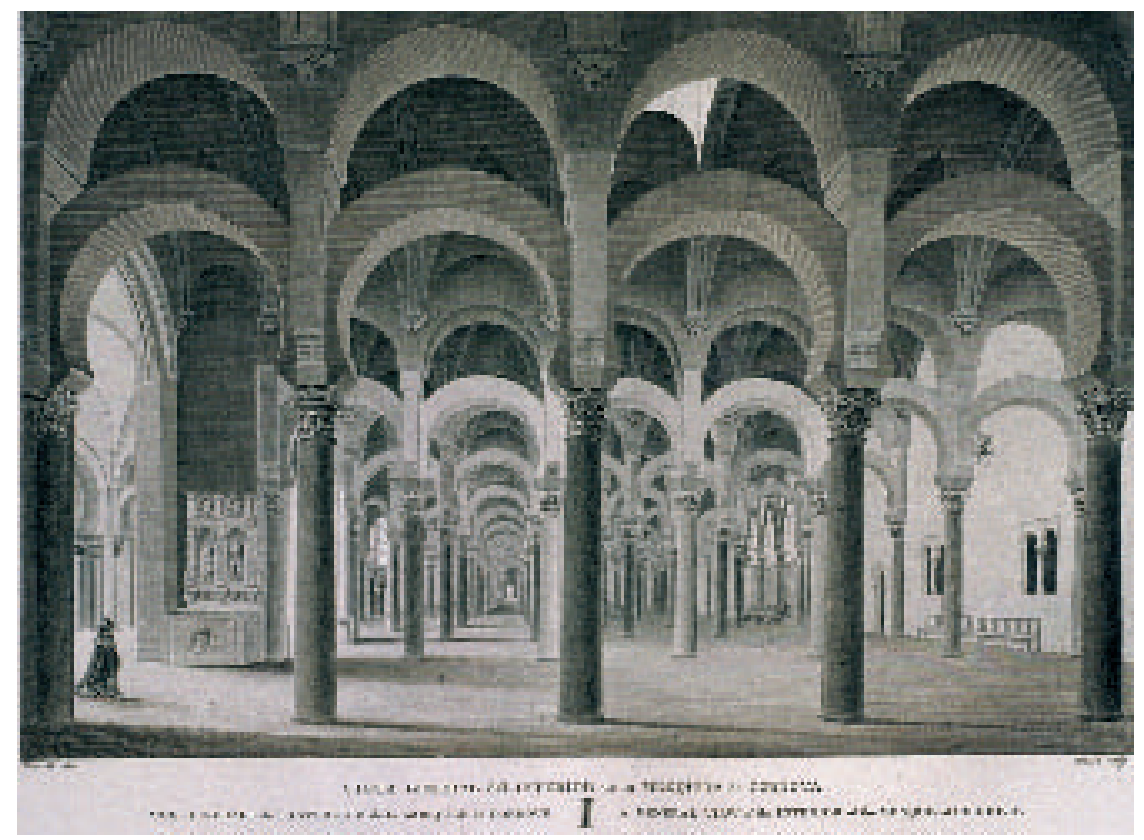

Fig. 7. Plancha XI. Vista general del interior de la Mezquita de Córdoba. Vauzelle (dib.), Benoist (grab.).

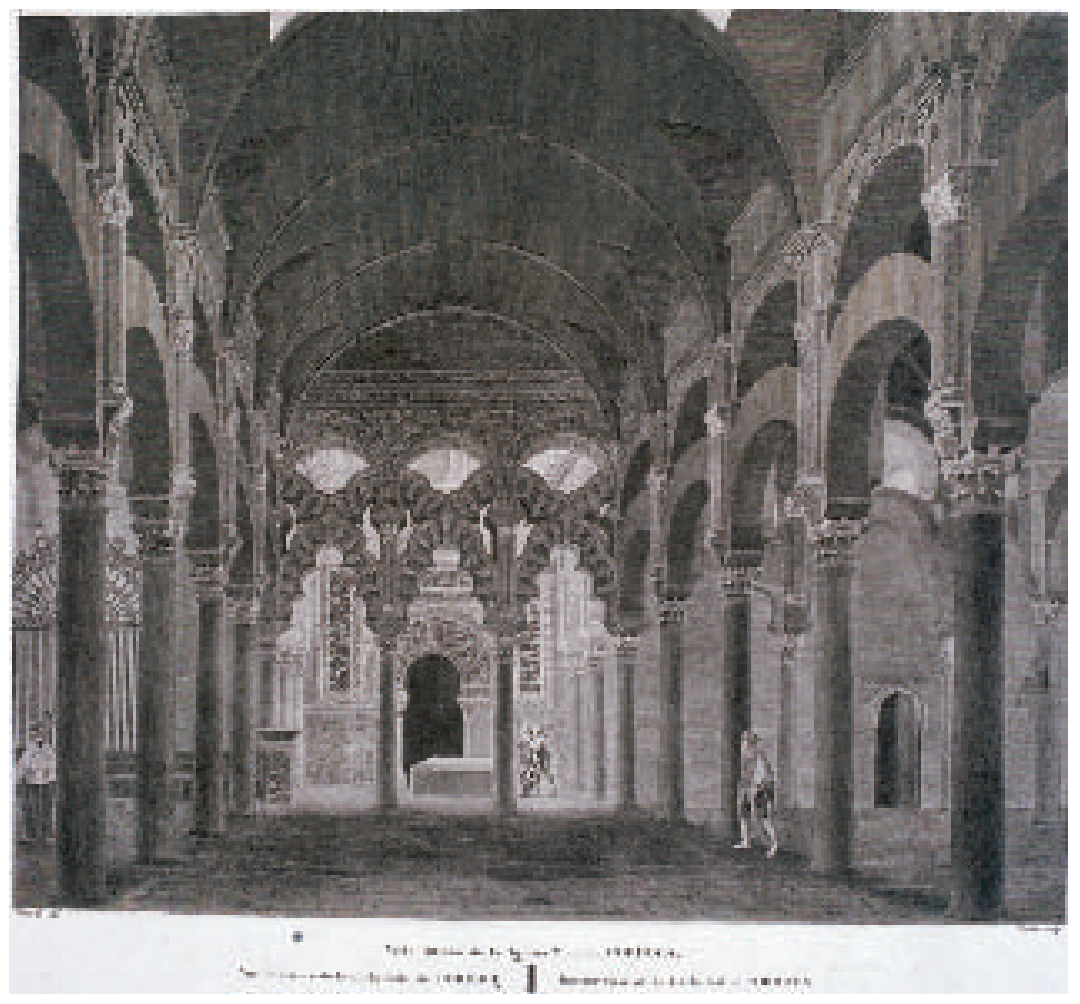

Fig. 8. Plancha XIII. Vista interior de la Iglesia Mayor de Córdoba. Vauzelle (dib.), Texier (grab.).

Arch. esp. arte, LXXXV, 338, ABRIL-JUNIO 2012, 105-124, ISSN: 0004-0428 


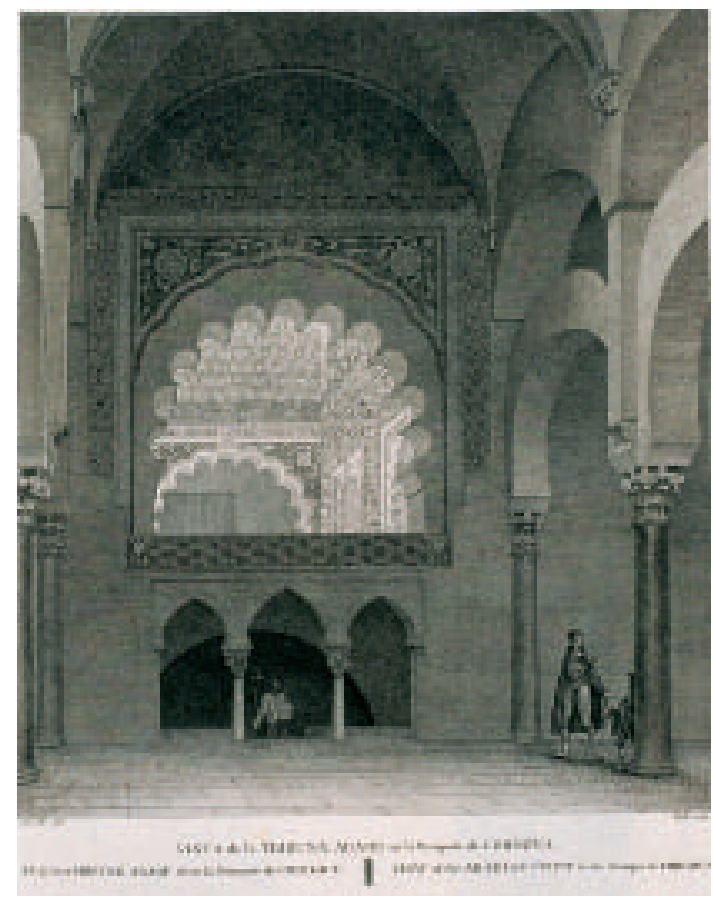

Fig. 9. Plancha XXV. Vista de la Tribuna Árabe en la Mezquita de Córdoba. Vauzelle (dib.), Hule (grab.).

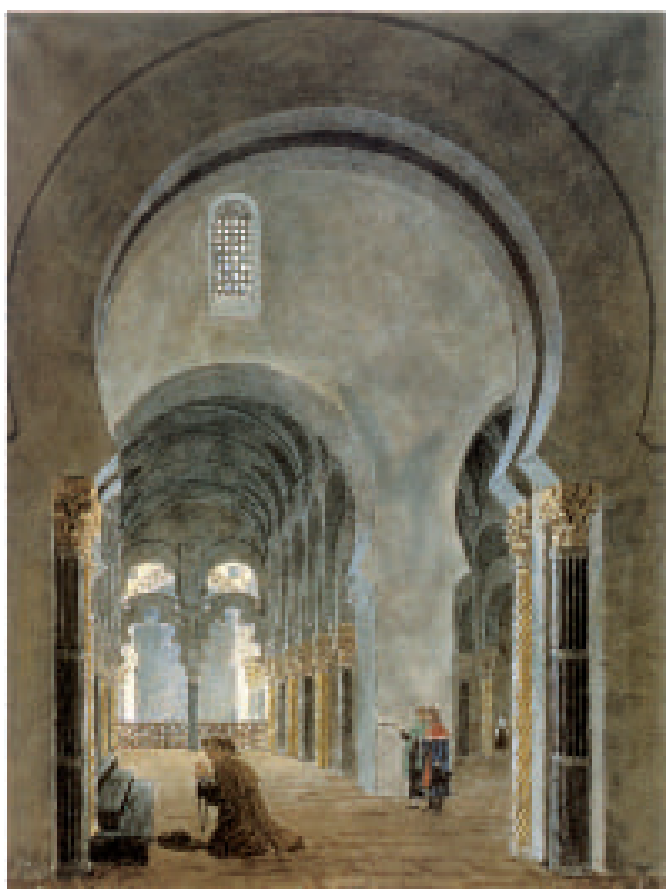

Fig. 10. Vista interior de la Mezquita. Vauzelle (dib.) [original en paradero desconocido] (en Quesada, L.: Pintores españoles y extranjeros en Andalucía, Sevilla, 1996, p. 73).

acceso al Sabat, que el dibujante debía haber detallado al fondo. La iluminación parece irreal y la nave gótica de 1589 se representa demasiado simplificada, con paramentos planos encalados. En todo caso, el punto de vista es muy interesante, al mostrarse cómo la implantación de esta primera iglesia supo respetar la permeabilidad visual hacia la Qibla, a la vez que funcionaba en sentido este-oeste, sirviendo de presbiterio el antiguo lucernario de al-Hakam II. Seguramente estamos ante uno de los tanteos previos que debieron realizarse para seleccionar puntos de vista y acometer después dibujos más detallados.

Figura 11. Vista de la Iglesia moderna de la Mezquita de Córdoba, dibujo a lápiz atribuido a Ligier (Museu Nacional d'Art de Catalunya). La imagen se tomó desde el coro situado en la nave central cristiana del XVI, recogiendo con fidelidad el crucero catedralicio y el altar mayor. La minuciosidad del dibujo permite identificar las diferentes etapas de esta controvertida empresa constructiva, impulsada por el obispo don Alonso Manrique a partir de 1523. Los arranques muestran las formas tardogóticas de Hernán Ruiz el viejo, maestro mayor hasta 1547, mientras que el piso superior del crucero y capilla mayor, con sus serlianas clasicistas, son de Hernán Ruiz el joven (1547-57). Arriba se dibujan la bóveda de terceletes y combados del presbiterio (1568), la cúpula elíptica del crucero (1599-1600) y la bóveda del coro, estas últimas de Juan de Ochoa.

Figura 12. Otra vista de la Iglesia moderna de la Mezquita de Córdoba, dibujo a lápiz atribuido a Ligier (Museu Nacional d'Art de Catalunya). Esta imagen refleja el brazo del crucero, visto de norte a sur desde uno de los arcos de ingreso, que en primer plano encuadra la composición. Una vez más se recogen con claridad las distintas fases arquitectónicas del edificio, destacándose la reutilización de arquerías islámicas como apoyo de los flancos este y oeste de los 


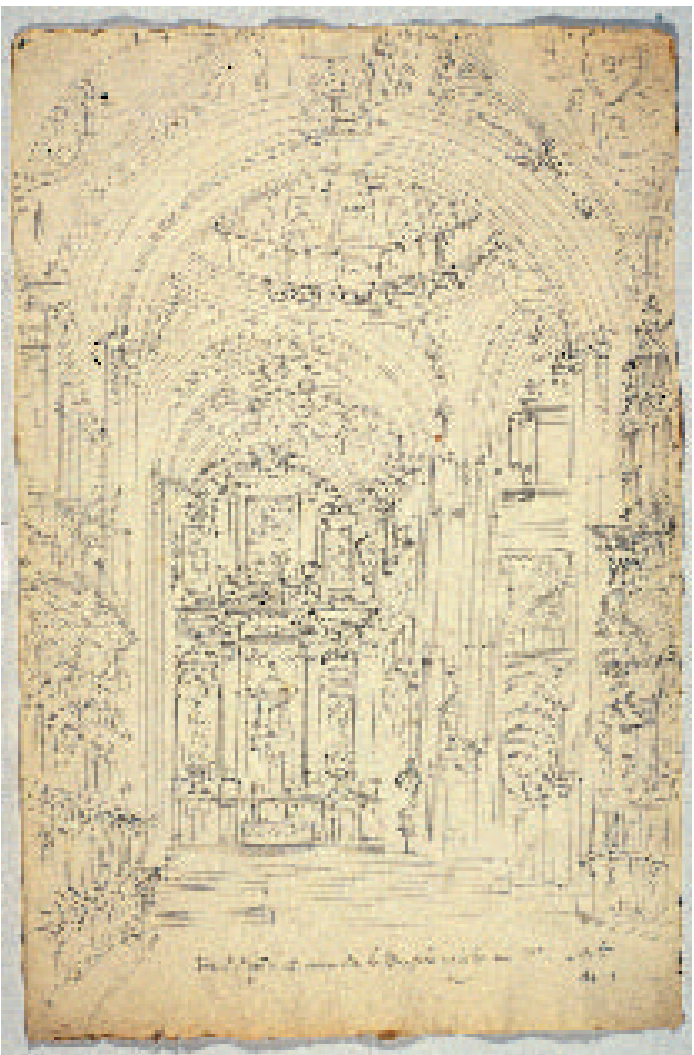

Fig. 11. Vista de la Iglesia moderna de la Mezquita de Córdoba. [Ligier (dib.)]

(C) MNAC - Museu Nacional d'Art de Catalunya.

Barcelona. Fotógrafos: Calveras/Mérida/Sagristà.

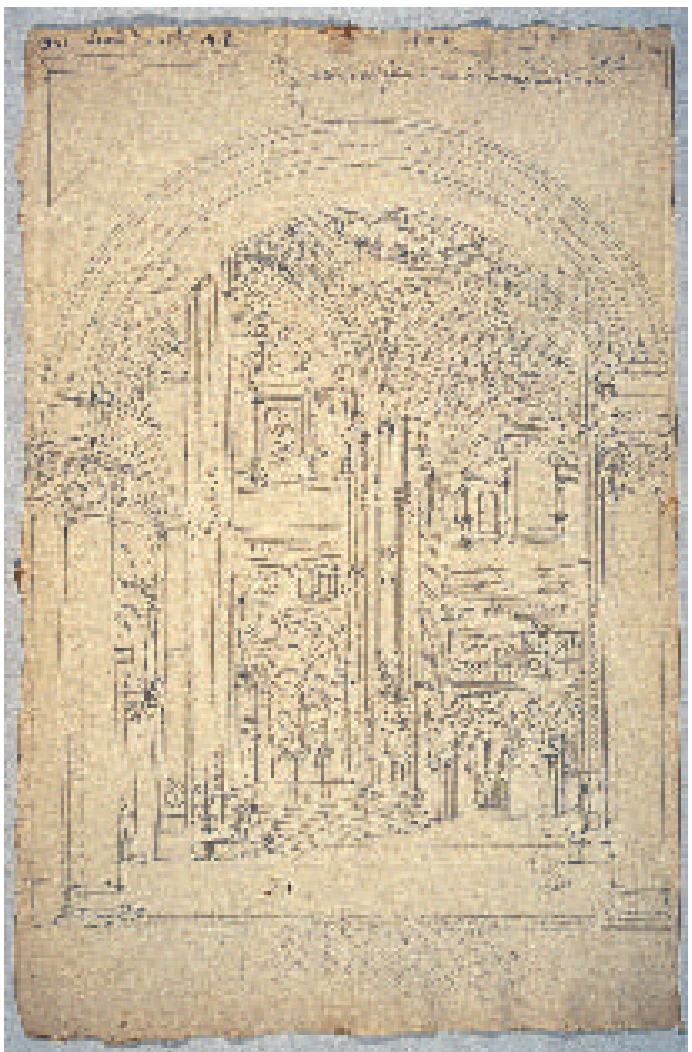

Fig. 12. Otra vista de la Iglesia moderna de la Mezquita de Córdoba. [Ligier (dib.)] (C) MNAC - Museu Nacional d'Art de Catalunya. Barcelona. Fotógrafos: Calveras/Mérida/Sagristà.

brazos del crucero. También se documentan importantes detalles hoy perdidos, como el pavimento de ladrillo colocado en el periodo bajomedieval cristiano, sustituyendo al original islámico de albero con cal pintado de almagra.

\section{Planos generales de planta, secciones y detalles arquitectónicos}

La planimetría que acompaña a las vistas de Laborde es una cuidada copia de la ya citada publicación de la Real Academia de San Fernando, manteniendo aspectos como la escala (basada en el pie castellano), los grafismos para distinguir fases edilicias y la rotulación de los distintos ámbitos. En la plancha VII (Dormier, grab.) se dibujó una planta hipotética de la Mezquita en tiempos de los árabes, y en la plancha VIII (Moulinier, dib.; Rousseau, grab.) otra planta de su estado hacia 1800. Las dos secciones de la plancha XVI (Rousseau, grab.) no incluyen los arbotantes de la Catedral, el trascoro o el tabicado del acceso al lucernario de al-Hakam II. Además de estas omisiones, el uso de los planos de la Real Academia de San Fernando llevó a Laborde a secundar hipótesis dudosas o erróneas sobre el edificio: la atribución cristiana de la torre; la omisión de los restos del primer muro de la Qibla, identificables por unos grandes machones dibujados en planta entre las arquerías actuales; la discutible filiación islámica de la Capilla Real; 
o la formalización del sabat, incoherente con su original carácter de pasaje y espacio privado del califa.

Además, Laborde aporta planos de detalles propios. La plancha XIV, Puerta del Sagrario del Corán en Córdoba (Vauzelle, dib.; Normand fils, grab.), se dedica al Mihrab de la Mezquita, recogido con gran fidelidad en proporciones generales, pero con desigual acierto en sus aspectos decorativos. Entre éstos destaca la transcripción de la faja epigráfica perimetral de mosaico, con zonas de texto perdidas, que constituye una interesante prueba documental para diferenciar la parte auténtica de lo rehecho en el siglo XIX. La plancha XXI, Puerta lateral de la Mezquita de Córdoba (Vauzelle, dib.; Schwartz, grab.), reproduce la puerta de San Esteban, la más antigua del edificio, por entonces en estado ruinoso y que hoy subsiste parcialmente.

Los dibujos de pilastras, capiteles, fragmentos e inscripciones árabes se reparten entre las planchas XVII, XVIII, XIX y XX, y en el Museu Nacional d'Art de Catalunya se conserva un dibujo preliminar de un capitel que no llegó a grabarse. Laborde copió de la publicación de la Real Academia de San Fernando las columnas miliarias romanas y las inscripciones árabes, aunque en este caso redistribuyó las leyendas en un mayor número de fajas epigráficas. En cambio, son originales las reproducciones de las estatuas romanas y los 21 capiteles repartidos en dos planchas, así como los detalles de las pilastras superiores en las arquerías de la nave del Mihrab.

\section{BIBLIOGRAFÍA}

Caballero Rodríguez, José, Alejandro de Laborde y Mérida. Pequeña historia de grandes grabados, Mérida, Artes Gráficas Rejas, 2004.

Cabra Loredo, María Dolores, "La España prerromántica de Alexandre Laborde”, Historia 16, n. ${ }^{\circ}$ 103, 1984, pp. 23-32.

Casanovas i Miró, Jordi y Quilez i Corella, Francesc M. (comisarios), El viatge a Espanya d'Alexandre de Laborde, Barcelona, cat. exp., Museu Nacional d'Art de Catalunya, 2006 (con textos de F. Quílez, J. Casanovas, Z. Mezinski, J. Yeguas, A. Curto, J. M. Álvarez, A. López, E. Hernández, T. Nogales, P. Marinetto, C. Salom, D. Caralt, R. Aceña y M. R. Manote).

Cosano Moyano, Francisco, Iconografía de Córdoba, Córdoba, Cajasur, 1999.

Damiron, Suzanne, "Dessins originaux pour l'illustration du Voyage Pittoresque et Historique de L'Espagne d'Alexandre de Laborde", Actas del XXIII Congreso Internacional de Historia del Arte. España entre el Mediterráneo y el Atlántico, Universidad de Granada, 1973, vol. 2, pp. 484-486.

D’Ormeson, François y Thomas, Jean-Pierre, Jean-Joseph de Laborde, banquier de Louis XV, mécène des Lumières, París, Perrin, 2002.

Ecker, Heather, "The Great Mosque of Córdoba in the twelfth and thirteenth centuries", Muqarnas, n. ${ }^{\circ} 20$, Leiden, 2003, pp. 113-141.

Gámiz Gordo, Antonio, "Las vistas de España del viajero David Roberts, pintor de paisajes y arquitecturas, hacia 1833", EGA, n. ${ }^{\circ} 15$, Valencia, 2010, pp. 54-65.

Laborde, Alexandre de, Description d'un pavé en mosaïque, decouvert dans l'ancienne ville d'Itàlica, aujourd'hui le village de Santiponce, près de Sevilla; suivie de recherches sur la peinture en mosaïque chez les anciens, et les monuments en ce genre qui n'ont piont encore été publies, París, Pierre Didot, 1802.

Laborde, Alexandre de, Exposición de dibujos para la ilustración del "Voyage pittoresque et historique de l'Espagne" de Alexandre de Laborde, [1800-1806], Barcelona, octubre-noviembre 1960.

Laborde, Alexandre de, Viatge a través de l'obra de'Alexandre de Laborde: Dibuixos, Gravats i porcellanes, [1800-1806], Barcelona, Artur Ramon Art, maig-juny 1989.

Laborde, Alexandre de, Voyage pittoresque et historique de l'Espagne, 4 vols., París, Pierre Didot, 1806, $1811,1812,1820$.

Laborde, Alexandre de, Viatge pintoresc i històric. El principat. Alexandre de Laborde (traducció i pròleg d'Oriol Valls; notes de J. Massot), Barcelona, [1806] 1974.

Arch. esp. arte, LXXXv, 338, ABRIL-JUNIO 2012, 105-124, ISSN: 0004-0428 
Laborde, Alexandre de, Viatge Pintoresc i históric. El país Valencià i les illes Balears (traducció i apéndix d'Oriol Valls; notes de J. Massot), Barcelona, [1811] 1975.

López Ontiveros, Antonio, "Esplendor y decadencia de Córdoba según Laborde”, en Casanovas, J. y Quilez, F. (comisarios), El viatge a Espanya d'Alexandre de Laborde, Barcelona, cat. exp., MNAC, 2006, pp. 186-188.

Llorens, Núria, "Las escenas de paisaje en el Viaje a España de Alexandre de Laborde", Anuario del Departamento de Historia y Teoría del Arte, vol. XIX, Barcelona, 2007. pp. 159-177.

Marfil Ruiz, Pedro, "Nuevos datos para el conocimiento del lucernario de al-Hakam II en la Capilla de Villaviciosa de la Mezquita de Córdoba”, Qurtuba, n. ${ }^{\circ}$ 3, Córdoba, 1998, pp. 252-253.

Marfil Ruiz, Pedro, "Estudio de las linternas y el extradós de las cúpulas de la Maqsura de la Catedral de Córdoba, antigua Mezquita Aljama", Arqueología de la Arquitectura, n. ${ }^{\text {3 }, ~ 2004, ~ p p . ~ 91-107 . ~}$

Mezinski, Zenon, "La figura de Alexandre de Laborde", en Casanovas, J. y Quilez, F. (comisarios), El viatge a Espanya d'Alexandre de Laborde, Barcelona, cat. exp., MNAC, 2006, pp. 235-238.

Moneo, Rafael, "La vida de los edificios. Las ampliaciones de la Mezquita de Córdoba, Arquitectura, n. ${ }^{\circ} 256$, Madrid, COAM, sept.-oct. 1985, pp. 27-36.

Mora, Gloria, "Voyage et itinéraire, de las descripciones de España en la segunda mitad del XVIII y primera mitad del XIX”, en Casanovas, J. y Quilez, F. (comisarios), El viatge a Espanya d'Alexandre de Laborde, Barcelona, cat. exp., MNAC, 2006, pp. 232-235.

Moret, Xavier (texto), Mora, Domi (fot.), Pedraza, Pilar (prólogo), Viaje por España tras los pasos de Laborde, Bancaja, 2006.

Nieto Cumplido, Manuel y Luca de Tena y Alvear, Carlos, La Mezquita de Córdoba: planos y dibujos, Córdoba, COAAO, 1992.

Nieto Cumplido, Manuel, La Catedral de Córdoba, Córdoba, Cajasur, 1998.

Ponz, Antonio, Viage de España, 18 tomos, 1772-1794.

Quesada, Luis, Pintores españoles y extranjeros en Andalucía, Sevilla, 1996.

Quilez i Corella, Francesc M., “Aproximación a las fuentes literarias del Voyage pittoresque et historique de l'Espagne”, en Casanovas, J. y Quilez, F. (comisarios), El viatge a Espanya d'Alexandre de Laborde, cat. exp., MNAC, Barcelona, 2006, pp. 244-249.

Real Academia de Bellas Artes de San Fernando (ed.), Las Antigüedades Árabes de España, Madrid, Imprenta Real, vol. I, 1787, vol. II, 1804.

Rodríguez Ruiz, Delfín, La memoria frágil. José de Hermosilla. Las Antigüedades Árabes de España, COAM, Madrid, 1992.

Rueda Roigé, Francesc Josep, "El mosaico del circo documentado en Itálica”, Locvs Amcenvus, 7, 2004, pp. 7-25.

Ruiz Cabrero, Gabriel, "La Mezquita-Catedral de Córdoba. Dieciséis proyectos de Velázquez Bosco", Arquitectura, n. ${ }^{\circ}$ 256, Madrid, COAM, sept.-oct. 1985, pp. 47-56.

San Antonio Gómez, Carlos de, "Los dibujos de Ricardo Velázquez y de Antonio Flórez para la Mezquita de Córdoba", EGA, n. ${ }^{\circ}$ 13, Valencia, 2008, pp. 180-189.

Tormo, Elías, Centenario de Alexandre de Laborde, el hispanista magnánimo, Viuda de Estanislao Maestre, Madrid, 1944 [tirada aparte del Boletín de la Real Academia de la Historia, tomo CXIII, cuaderno II, Madrid, octubre-diciembre 1943].

Torres Balbás, Leopoldo, La Mezquita de Córdoba y Madinat Al-Zahra, Madrid, Plus Ultra, 1952.

Fecha de recepción: 14-II-2011

Fecha de aceptación: 15-VI-2011 